\title{
PENGARUH PEMBERIAN EKSTRAK ETANOL BUNGA KECOMBRANG (Etlingera elatior (Jack) R. M. Sm.) TERHADAP KADAR MALONDIALDEHID (MDA) MENCIT PUTIH JANTAN HIPERLIPIDEMIA
}

\author{
Ria Afrianti' ${ }^{1}$ Windy Agnes $^{1}$ Herdissa $^{1}$ \\ ${ }^{1}$ Fakultas Farmasi, Universitas Perintis Indonesia \\ Email : afrianti81@gmail.com
}

\begin{abstract}
ABSTRAK
Hiperlipidemia merupakan suatu keadaan patologis yang disebabkan oleh kelainan lipid darah sehingga meningkatkan kadar kolesterol darah. Kadar kolesterol yang meningkat dalam darah akan mengakibatkan meningkatnya produksi radikal bebas sehingga terjadi stress oksidatif dan menyebabkan kadar malondialdehid meningkat. Penelitian ini bertujuan untuk mengetahui pengaruh pemberian ekstrak etanol bunga kecombrang (Etlingera elatior (Jack) R. M. Sm.) terhadap kadar malondialdehid (MDA) mencit putih jantan hiperlipidemia. Pengukuran kadar malondialdehid dilakukan dengan uji TBA (Thio Barbituric Acid) reactivity test. Pada penelitian ini hewan percobaan dibagi menjadi 5 kelompok yaitu kelompok kontrol negatif, kelompok kontrol positif, kelompok dosis ekstrak $100 \mathrm{mg} / \mathrm{kgBB}$, kelompok dosis ekstrak $200 \mathrm{mg} / \mathrm{kgBB}$ dan kelompok dosis ekstrak $400 \mathrm{mg} / \mathrm{kgBB}$. Nilai ratarata kadar MDA dari kelompok negatif : $2,40 \mathrm{nmol} / \mathrm{ml}$, kelompok positif : $4,19 \mathrm{nmol} / \mathrm{ml}$, kelompok dosis $100 \mathrm{mg} / \mathrm{kgBB}: 3,67 \mathrm{nmol} / \mathrm{ml}$, kelompok dosis $200 \mathrm{mg} / \mathrm{kgBB}: 2,59 \mathrm{nmol} / \mathrm{ml}$ dan kelompok dosis $400 \mathrm{mg} / \mathrm{kgBB}: 2,47 \mathrm{nmol} / \mathrm{ml}$. Nilai rata-rata kadar MDA kelompok dosis $200 \mathrm{mg} / \mathrm{kgBB}$ dan $400 \mathrm{mg} / \mathrm{kgBB}$ secara signifikan ( $<<0,05)$ mendekati nilai rata-rata MDA kelompok kontrol negatif. Jadi dapat disimpulkan bahwa pemberian ekstrak etanol bunga kecombrang dapat menurunkan kadar MDA mencit putih jantan hyperlipidemia
\end{abstract}

Keywords : Etlingera elatior (Jack) R. M. Sm., hiperlipidemia, Malondialdehid.

\begin{abstract}
Hyperlipidemia is a pathological condition caused by blood lipid abnormalities that increase blood cholesterol levels. Increased cholesterol levels in the blood will lead to increased production of free radicals resulting in stress oxidative and cause increased malondialdehyde (MDA) levels. This study was used to determine the level of MDA male white mice hyperlipidemia. Measurement of MDA levels was done by TBA (thio Barbituric Acid) reactivity test. In this research used 5 group : negative control group, positive control group, dose of extract $100 \mathrm{mg} / \mathrm{kgBW}$ group, dose of extract $200 \mathrm{mg} / \mathrm{kgBW}$ group and dose of extract 400 $\mathrm{mg} / \mathrm{kgBW}$ group. The mean values of MDA levels of negative group : $2,40 \mathrm{nmol} / \mathrm{ml}$, positive group : $4,19 \mathrm{nmol} / \mathrm{ml}$, dose 100 $\mathrm{mg} / \mathrm{kgBW}$ group : $3,67 \mathrm{nmol} / \mathrm{ml}$ dose $200 \mathrm{mg} / \mathrm{kgBW}$ group : $2.59 \mathrm{nmol} / \mathrm{ml}$ and dose $400 \mathrm{mg} / \mathrm{kgBW}$ group : $2.47 \mathrm{nmol} / \mathrm{ml}$. The mean value of MDA group dose of $200 \mathrm{mg} / \mathrm{kgBW}$ and $400 \mathrm{mg} / \mathrm{kgBW}$ was significantly ( $<<0.05$ ) approach to the average MDA value of the negative control group. So it can be concluded the administration of ethanol extract of kecombrang flowers can decrease MDA levels of hyperlipidemic male white mice.
\end{abstract}

Keywords : Etlingera elatior (Jack) R. M. Sm., Hyperlipidemia, Malondialdehyde.

\section{PENDAHULUAN}

Hiperlipidemia merupakan suatu keadaan patologis yang disebabkan oleh kelainan metabolisme lipid darah yang ditandai dengan meningkatnya kadar kolesterol total, trigliserida, Low Density Lipoprotein (LDL) serta penurunan kadar High Density Lipoprotein (HDL) (Heryani, 2016). Kondisi hiperlipidemia merupakan salah satu faktor yang dapat memicu penebalan dinding pembuluh darah sehingga dapat menyebabkan penyempitan dan pengerasan pada pembuluh darah arteri yang disebut aterosklerosis (Rahayu, 2005).

Kadar kolesterol yang meningkat di dalam darah mampu menginduksi terbentuknya radikal bebas atau Reactive Oxygen Species (ROS). Radikal bebas timbul akibat berbagai proses kimiawi dalam tubuh, metabolisme sel, dan peradangan (Helmizar et al., 2010). Apabila jumlah radikal bebas banyak di dalam darah, maka hal tersebut dapat menyebabkan stres oksidatif (Latifa, 2015).

Stress oksidatif terjadi akibat peroksidasi lipid dimana radikal bebas menyerang asam lemak tidak jenuh ikatan ganda (Poly Unsuturates Fatty Acid) dan terbentuk produk seperti malondialdehid (MDA), sehingga salah satu parameter yang dapat menentukan stress oksidatif adalah dengan mengukur kadar malondialdehid (Valco, et al., 2006).

Malondialdehid (MDA) merupakan produk yang sangat beracun yang sebagian 
diproduksi dari peroksidasi lipid yang merupakan turunan dari produk radikal bebas. Radikal bebas dapat meningkatkan peroksidasi lipid yang kemudian akan mengalami dekomposisi menjadi malondialdehyde (MDA) dalam darah. Uji MDA dapat digunakan untuk mengukur peroksidasi yang terjadi pada membran lipid. Profil MDA dalam serum berfungsi sebagai sebuah penanda kerusakan seluler akibat radikal bebas (Latifa, 2015). Zat penunda atau pencegah terjadinya stres oksidatif disebut antioksidan (Manimaran et al., 2009)

Antioksidan adalah molekul yang saling berhubungan dengan radikal bebas dan menangkal reaksi berantai dari radikal bebas sebelum molekul-molekul penting dirusaknya. Untuk melawan bahaya radikal bebas, tubuh telah mempersiapkan penangkal melalui sistem antioksidan (Soobrattee, 2005). Antioksidan bekerja dengan cara mendonorkan satu elektronnya kepada senyawa yang bersifat oksidan sehingga aktivitas senyawa oksidan tersebut bisa terhambat dan radikal bebas akan menjadi stabil dan tidak toksik (Winarsi, 2007)

Kecombrang merupakan salah satu jenis sayuran yang sejak lama dikenal dan dimanfaatkan oleh manusia sebagai obat-obatan yang khasiatnya sebagai anti bakteri. Bagian yang biasa digunakan dari tanaman ini adalah bunga, daun dan batangnya (Kusumawati et al, 2015).

Selain sebagai anti mikroba, kecombrang juga merupakan antioksidan alami (Naufalin et al., 2016). Hasil penelitian sebelumnya yang dilakukan oleh Jaffar et al., 2007 pada daun, batang, bunga dan rimpang tanaman ini menunjukkan adanya senyawa metabolit sekunder yang bersifat bioaktif. Adapun komponen senyawa bioaktif yang terdapat pada bunga kecombrang adalah terpenoid, polifenol dan flavonoid, komponenkomponen tersebut merupakan senyawa antioksidan yang mampu menangkal radikal bebas (Naufalin et al., 2016).

Berdasarkan penelitian sebelumnya yaitu pengujian antioksidan ekstrak bunga kecombrang secara invitro, maka peneliti tertarik untuk menguji efek antioksidan dari ektrak etanol bunga kecombrang secara invivo yaitu dengan cara mengukur kadar MDA (malondialdehid) pada mencit putih jantan hiperlipidemia yang di induksi dengan MLT (Makanan Lemak Tinggi) dan PTU (Propiltiourasil).

\section{METODE PENELITIAN}

\section{Alat dan Bahan}

Alat-alat

Alat-alat yang digunakan adalah seperangkat alat rotary evaporator, alat pengukur kolesterol dan strip test, alat sentrifus, vortex mixer, waterbath dan spektrofotometer UV-Vis.

\section{Bahan}

Bahan yang digunakan adalah bunga kecombrang, etanol 96\%, aquadest, Na.CMC, lemak daging, kuning telur, propiltiourasil, dan air.

\section{PELAKSANAAAN PENELITIAN}

\section{Pengambilan Sampel}

Sampel yang diambil dalam penelitian ini adalah bunga kecombrang yang di peroleh dari Arosuka, Kab. Solok, Sumatera Barat.

\section{Penyiapan Bahan Uji}

a. Pembuatan suspensi Na. CMC

Sebanyak 0,5 g Na-CMC ditaburkan dalam lumpang yang berisi $20 \mathrm{ml}$ air suling panas. Ditutup dan didiamkan selama 30 menit hingga diperoleh massa yang transparan, lalu digerus sampai homogen, diencerkan dengan air suling hingga $100 \mathrm{ml}$.

\section{b. Pembuatan suspensi sediaan uji}

Sebelum diberikan pada hewan percobaan, sedian uji ekstrak kental terlebih dahulu dibuat dalam suspensi menggunakan Na.CMC 0,5\%. Caranya: timbang Na.CMC sebanyak $50 \mathrm{mg}$ untuk tiap-tiap kelompok dosis ekstrak uji dan ditaburkan dalam $10 \mathrm{ml}$ air panas, biarkan selama 15 menit dan gerus hingga membentuk massa yang homogen. Kemudian masukkan ekstrak kental bunga kecombrang sesuai dengan dosis sediaan uji dan masukkan ke dalam suspensi yang ada di dalam lumpang, lalu tambahkan air sebanyak $100 \mathrm{ml}$ dan gerus hingga homogen.

c. Pembuatan makanann lemak tinggi (MLT)

Timbang 5 gram lemak sapi, 10 gram kuning telur, dan air sampai $100 \mathrm{ml}$. Cara pembuatannya yaitu dengan memanaskan lemak sapi yang berupa padatan sehingga diperoleh bentuk cair (minyak lemak sapi). Kemudian mencampur minyak sapi tersebut dengan kuning telur sehingga terbentuk korpus emulsi, kemudian ke dalam korpus emulsi tersebut ditambahkan air sampai $100 \mathrm{ml}$ sambil diaduk 
cepat hingga terbentuk emulsi yang halus dan homogen (Widyaningsih, 2011).

\section{d. Pembuatan larutan Propiltiourasil (PTU)}

Dosis PTU yang diberikan kepada mencit adalah $0,26 \mathrm{mg} / 20 \mathrm{~g} \mathrm{bb}$, dosis PTU yang diberikan untuk manusia adalah $100 \mathrm{mg}$. VAO (Volume Administrasi Obat) PTU yang diberikan kepada mencit adalah $1 \%$ dari berat badan mencit normal $(20 \mathrm{~g})$.

\section{Dosis Uji yang Digunakan}

Dosis pemberian ekstrak yang diberikan pada mencit adalah $100 \mathrm{mg} / \mathrm{kgBB}, 200 \mathrm{mg} / \mathrm{kgBB}$ dan $400 \mathrm{mg} / \mathrm{kgBB}$.

\section{Perlakuan Hewan Percobaan}

- Sebelum percobaan, hewan percobaan (mencit) diaklimatisasi selama 1 minggu.

- Pada hari ke-8, hewan percobaan di puasakan selama 16 jam dan diukur kadar kolestrol awal setiap kelompok.

- Berikan penginduksi makanan lemak tinggi (MLT) dan propiltiourasil (PTU) pada kelompok kontrol positif, kelompok dosis $100 \mathrm{mg} / \mathrm{kgBB}$, kelompok dosis $200 \mathrm{mg} / \mathrm{kgBB}$ dan kelompok $400 \mathrm{mg} / \mathrm{kgBB}$.

- Kemudian pada hari ke-15 puasakan kembali hewan percobaan selama 16 jam dan ukur kembali kadar kolesterol setiap kelompok.

- Setelah itu berikan sediaan uji pada kelompok III, IV dan V selama 14 hari.

- Pengelompokan hewan percobaan adalah sebagai berikut :

- Kelompok I: Kontrol negatif, diberi pembawa yaitu suspensi Na. CMC

- Kelompok II: Kontrol positif, mencit putih jantan hiperlipidemia

- Kelompok III: Mencit putih hiperlipidemia dan diberi sediaan uji deng

- an dosis 100mg/kg BB

- Kelompok IV: Mencit putih jantan hiperlipidemia dan diberi sediaan uji dengan dosis 200mg/kg BB

- Kelompok V : Mencit putih jantan hiperlipidemia dan diberi sediaan uji dengan dosis $\quad 400 \mathrm{mg} / \mathrm{kg} \mathrm{BB}$

- Setelah 14 hari perlakuan pemberian ekstrak etanol bunga kecombrang, puasakan kembali hewan percobaan selama 16 jam kemudian ukur kadar kolesterol totalnya.

- Pada hari ke-29 seluruh hewan percobaan dari semua kelompok diambil darahnya dengan cara memotong pembuluh darah pada leher dan ditampung dengan tabung reaksi sebanyak lebih kurang $3 \mathrm{ml}$.
Pengukuran Kadar MDA serum mencit dengan metoda Modifikasi (PP.Nair)

Cara Kerja:

- Darah di sentrifuge, kemudian pisahkan serumnya.

- Siapkan tabung sesuai prosedur berikut :

Tabel 1. Jumlah bahan yang ditambahkan

\begin{tabular}{llll}
\hline Bahan & $\begin{array}{l}\text { Tabung } \\
\text { blanko }\end{array}$ & $\begin{array}{l}\text { Tabung } \\
\text { standar }\end{array}$ & $\begin{array}{l}\text { Tabung } \\
\text { sampel }\end{array}$ \\
\hline Aquadest & $0,5 \mathrm{ml}$ & - & - \\
Standard & - & $0,5 \mathrm{ml}$ & - \\
Serum & - & - & $0,5 \mathrm{ml}$ \\
Sampel & & & \\
\hline
\end{tabular}

- Tambahkan masing-masing 2,5 $\mathrm{ml}$ TCA 5\%

- Campur dengan menggunakan vortex mixer

- Sentrifuge selama 15 menit, dengan kecepatan 10.000 RPM

- Pipet $1 \mathrm{ml}$ filtrat (masing-masing tabung), masukan kedalam tabung sesuai dengan labelnya

- Tambahkan $1 \mathrm{ml}$ TBA

- Campur dengan menggunakan vortex mixer

- Panaskan dalam water bath mendidih selama 30 menit, lalu dinginkan

- Baca Absorban dengan Spektrofotometer pada $\lambda 530 \mathrm{~nm}$

\section{HASIL DAN PEMBAHASAN.}

Pada penelitian ini digunakan sampel berupa bunga kecombrang (Etlingera elatior (Jack) R. M. Sm.) yang diperoleh dari Arosuka, Kab. Solok, Sumatera Barat. Identifikasi sampel dilakukan di Herbarium Jurusan Biologi, Fakultas Matematika dan Ilmu Pengetahuan Alam, Universitas Negeri Andalas, Padang.

Ekstrak etanol bunga kecombrang didapatkan dengan cara melakukan ekstraksi sampel dengan metode maserasi. Metode ini dipilih karena prosesnya sederhana, cukup efektif untuk menarik zat yang diinginkan, tidak ada proses pemanasan sehingga dapat menghindari terjadinya kerusakan zat - zat akibat suhu yang tinggi. Sebelum dimaserasi, $1000 \mathrm{~g}$ sampel dibersihkan terlebih dahulu kemudian dirajang halus. Sampel yang digunakan adalah sampel segar, dan pelarut yang digunakan untuk proses ekstraksi ini adalah etanol 96\%. Maserasi dilakukan selama 5 hari sambil sekali - kali diaduk dan diulangi sebanyak tiga kali dengan cara yang sama. Setelah dilakukan maserasi selama 5 hari sampel 
disaring, campurkan semua maserat dari tiga kali proses pengulangan tersebut kemudian diuapkan dengan alat rotary evaporator hingga didapatkan ekstrak kental bunga kecombrang sebanyak 63,21 gram.

Rendemen ekstrak kental bunga kecombrang yaitu $6,321 \%$. Pemeriksaan yang dilakukan terhadap ekstrak meliputi susut pengeringan, kadar abu yang hasilnya berturut turut adalah $11,34 \%$ dan 3,98\%. Hasil pemeriksaan organoleptis yang dilakukan adalah bentuk : cairan kental, rasa : khas, bau : khas, warna : coklat pekat.

Hasil pemeriksaan pendahuluan dari kandungan kimia menunjukkan bahwa ekstrak etanol bunga kecombrang memiliki fenolik, flavonoid dan terpenoid. Selain itu, pemeriksaan menunjukkan hasil negatif terhadap uji saponin dan steroid. Hasil pemeriksaan kandungan kimia yang didapatkan sesuai dengan literatur, yang menunjukkan bahwa bunga kecombrang mengandung flavonoid, terpenoid dan fenolik (Naufalin et al, 2016).

Flavonoid merupakan suatu senyawa polar karena mempunyai sejumlah gugus hidroksil atau gugus gula. Dengan adanya gugus gula yang terikat pada flavonoid ini, maka cenderung menyebabkan flavonoid lebih mudah larut dalam air dan demikian campuran pelarut polar dengan air merupakan pelarut yang baik untuk glikosidanya (Harborne, 1987).

Bunga kecombrang merupakan salah satu tanaman di Indonesia yang sering digunakan sebagai bahan sayuran seperti pecel atau sebagai lalapan. Beberapa tahun terakhir ini, kecombrang menjadi pusat perhatian besar beberapa peneliti karena adanya aktivitas antibakteri dan antioksidan. Secara tradisional bunga kecombrang digunakan untuk menyembuhkan penyakit seperti campak, sakit telinga, memperbanyak ASI, sebagai deodorant dan obat luka (Saludung, 2015).

Hewan percobaan yang digunakan dalam penelitian ini adalah mencit putih jantan. Adapun alasan digunakan mencit diantaranya mudah didapat, mudah dalam penanganannya dan memiliki kemiripan fisiologis dengan manusia (Thompson, 1990). Sebelum dilakukan pengujian, terlebih dahulu hewan percobaan di aklimatisasi selama 1 minggu untuk menyesuaikan diri terhadap lingkungan sekitar. Hewan dinyatakan sehat yang digunakan dalam penelitian yaitu hewan yang selama pemeliharaan perubahan bobot hewan tidak melebihi $10 \%$. Hewan percobaan dikelompokkan atas 5 kelompok, tiap kelompok terdiri 3 ekor mencit.
Pada penelitian ini dilakukan pemberian sediaan uji dengan 3 variasi dosis yaitu ekstrak etanol bunga kecombrang dengan dosis I (100 $\mathrm{mg} / \mathrm{kg} \mathrm{BB})$, dosis II (200 mg/kg BB), dan dosis III (400 mg/kg BB). Pengukuran kadar kolesterol dilakukan pada saat sebelum hewan percobaan diinduksi (hari ke-8), setelah hewan percobaan diinduksi (hari ke-5) dan setelah pemberian sediaan selama 14 hari (hari ke-29).

Langkah awal penelitian ini dimulai dengan melakukan aklimatisasi selama 7 hari kemudian mencit dipuasakan selama 16 jam namun tetap diberi minum dengan tujuannya untuk menghindari peningkatan kadar kolesterol akibat makanan yang masuk. Sebelum pemberian penginduksi, dilakukan pengukuran kadar kolesterol normal mencit untuk mengetahui kadar kolesterol sebelum perlakuan sehingga dapat dibandingkan dengan kadar kolesterol setelah perlakuan. Setelah diinduksi, kadar kolesterol mencit akan meningkat dan mampu menyebabkan stress oksidatif dimana radikal bebas menyerang asam lemak tidak jenuh ikatan ganda (Poly Unsuturates Fatty Acid) sehingga meningkatkan produksi malondialdehid (Valco, et al., 2006). Kemudian induksi mencit dengan PTU dan MLT selama 7 hari lalu puasakan mencit selama 16 jam dan ukur kadar kolesterol mencit.

Kalau ada kenaikan kadar kolesterol setelah pemberian induksi pada hewan percobaan maka diberikan ekstrak etanol bunga kecombrang pada kelompok III, IV dan V, sedangkan untuk kelompok kontrol positif diberikan suspensi Na. CMC dan kelompok kontrol negatif tidak di berikan apa-apa, perlakuan ini dilakukan selama 14 hari kemudian puasakan mencit selama 16 jam dan ukur kadar kolesterol mencit lalu lakukan pengambilan darah pada leher, darah ditampung dalam mikrotube lalu disentrifus selama 20 menit dengan kecepatan 4000 RPM, diambil serumnya lalu disentrifus lagi selama 10 menit dengan kecepatan 2000 RPM agar di dapat serum yang lebih banyak. Serum darah yang didapat diperiksa kadar MDA nya dengan metode TBA (Thiobarbiturat Acid) Reactivity test. Analisa MDA dengan menggunakan metode TBA ( Thiobarbiturat Acid ) secara luas digunakan beberapa tahun terakhir untuk mengetahui level peroksidasi lipid serta radikal bebas (Tukozkan, 2006). Dimana rata-rata kadar malondialdehid (MDA) pada kelompok kontrol negatif, kontrol positif, dosis $100 \mathrm{mg} / \mathrm{kgBB}$, dosis $200 \mathrm{mg} / \mathrm{kgBB}$, $400 \mathrm{mg} / \mathrm{kgBB}$ masing-masing adalah 2,40 $\mathrm{nmol} / \mathrm{ml} ; 4,19 \mathrm{nmol} / \mathrm{ml} ; 3,67 \mathrm{nmol} / \mathrm{ml} ; 2,59$ $\mathrm{nmol} / \mathrm{ml}$; dan $2,47 \mathrm{nmol} / \mathrm{ml}$. 
Pada penelitian ini, hewan percobaan diinduksi dengan PTU dan MLT (makanan lemak tinggi). PTU (propilthiourasil) dapat menghambat sintesa hormone tiroid, pada keadaan normal hormontiroid dapat meningkatkan metabolisme lemak dengan cara meningkatkan pembentukan respon reseptor LDL. Oleh karena itu kekurangan hormon akibat PTU menyebabkan berkurangnya respon reseptor LDL sehingga terjadi peningkatan kadar lipoprotein darah terutama yang mengandung banyak kolesterol (Ganiswara, 1995). Sedangkan pemberian makanan lemak tinggi (MLT) dapat meningkatkan kadar kolesterol dan trigliserida secara bermakna, makanan lemak tinggi terdiri dari kuning telur dan lemak sapi, seperti yang diketahui kedua jenis makanan ini merupakan sumber kolesterol dan lemak secara eksogen (Juheini, 2002).

Pemberian induksi kolesterol secara endogen dan eksogen ini dipilih karena peneliti ingin membuat hewan percobaan sebagai model hiperlipidemia seperti yang dialami oleh manusia. Seperti yang diketahui MLT (makanan lemak tinggi) adalah makanan yang banyak mengandung kolesterol dan PTU (propiltiourasil) dapat membantu mempercepat terjadinya hiperlipidemia secara endogen (dari dalam tubuh). Alasan lain penggunaan induksi MLT dan PTU karena MLT dan PTU mudah didapat dan harganya lebih terjangkau.

Pada penelitian ini, kadar kolesterol total darah mencit diukur menggunakan alat digital yakni EasyTouch. Alat ini lebih praktis digunakan untuk pengukuran kadar kolesterol total darah mencit karena hanya membutuhkan sedikit darah dan kadar kolesterol cepat terbaca.

Penimbangan berat badan mencit dilakukan setiap hari, hal ini dilakukan untuk melihat pengaruh kolesterol terhadap berat badan. Biasanya keadaan kolesterol kronik mampu menaikkan berat badan secara perlahan karena adanya kelebihan lemak yang di simpan di jaringan adiposa dibawah kulit atau rongga perut. Setiap lemak dan karbohidrat makanan yang tidak langsung digunakan akan disimpan di jaringan adiposa dalam bentuk trigliserida. Semakin banyak lemak yang tersimpan, berat badan juga akan semakin meningkat.

Kadar kolesterol yang meningkat di dalam darah mampu menginduksi terbentuknya radikal bebas atau Reactive Oxygen Species (ROS) sehingga terbentuklah malondialdehid (MDA) (Valco, et al., 2006). Kadar malondialdehid yang diukur pada penelitian ini adalah kadar malondialdehid serum mencit. Serum mencit ini dipilih karena profil MDA dalam serum berfungsi sebagai sebuah penanda kerusakan seluler akibat radikal bebas (Latifa, 2015). Malondialdehid adalah senyawa dialdehid yang merupakan hasil peroksidasi lipid. Peroksidasi lipid diperoleh dari rekasi antara radikal bebas dengan asam lemak tak jenuh (Marsk, et al., 2000). Reaksi yang berlangsung terus menerus membentuk reaksi berantai dan menyebabkan membran kehilangan asam lemak tak jenuhnya. Akibatnya terjadi kerusakan struktur sel membran yang akan mempengaruhi permeabilitas dan fungsi membran sel. Untuk menghentikan reaksi tersebut diperlukan suatu bahan yang dapat menetralisir keberadaan radikal bebas dalam tubuh yaitu antioksidan.

Pemberian sediaan uji diberikan dalam 3 variasi dosis yaitu: Dosis $100 \mathrm{mg} / \mathrm{kgBB}$, dosis $200 \mathrm{mg} / \mathrm{kgBB}$ dan dosis $400 \mathrm{mg} / \mathrm{kgBB}$ secara peroral. Kadar rata-rata MDA pada kelompok I $\mathrm{V}$ berturut-turut adalah $2,40 \mathrm{nmol} / \mathrm{mL}, 4,19$ $\mathrm{nmol} / \mathrm{mL}, 3,67 \mathrm{nmol} / \mathrm{mL}, 2,59 \mathrm{nmol} / \mathrm{mL}, 2,47$ $\mathrm{nmol} / \mathrm{ml}$.

Tabel 2. Hasil penetuan kadar MDA

\begin{tabular}{|c|c|c|}
\hline Kelompok & HP & $\begin{array}{c}\text { Kadar MDA } \\
(\mathrm{nmol} / \mathrm{ml})\end{array}$ \\
\hline Kelompok & 1 & 3,29 \\
\hline I & 2 & 2,03 \\
\hline $\begin{array}{l}\text { (Kontrol } \\
\text { negatif) }\end{array}$ & 3 & 1,88 \\
\hline $\begin{array}{l}\text { Rata-rata } \pm \\
\text { SD }\end{array}$ & & $2,40 \pm 0,77$ \\
\hline Kelompok & 1 & 3,70 \\
\hline II & 2 & 4,48 \\
\hline $\begin{array}{l}\text { (Kontrol } \\
\text { positif) }\end{array}$ & 3 & 4,38 \\
\hline $\begin{array}{c}\text { Rata-rata } \pm \\
\text { SD }\end{array}$ & & $4,19 \pm 0,42$ \\
\hline Kelompok & 1 & 3,44 \\
\hline III & 2 & 3,49 \\
\hline $\begin{array}{l}\text { ( dosis } 100 \\
\mathrm{mg} / \mathrm{kg} \mathrm{BB})\end{array}$ & 3 & 4,07 \\
\hline $\begin{array}{c}\text { Rata-rata } \pm \\
\text { SD }\end{array}$ & & $3,67 \pm 0,35$ \\
\hline Kelompok & 1 & 2,56 \\
\hline IV & 2 & 2,82 \\
\hline $\begin{array}{c}(\text { dosis } 200 \\
\mathrm{mg} / \mathrm{kg} \mathrm{BB})\end{array}$ & 3 & 2,40 \\
\hline $\begin{array}{c}\text { Rata-rata } \pm \\
\text { SD }\end{array}$ & & $2,59 \pm 0,21$ \\
\hline Kelompok & 1 & 2,14 \\
\hline V & 2 & 2,71 \\
\hline $\begin{array}{c}(\text { dosis } 400 \\
\mathrm{mg} / \mathrm{kg} \mathrm{BB})\end{array}$ & 3 & 2,56 \\
\hline $\begin{array}{c}\text { Rata-rata } \pm \\
\text { SD }\end{array}$ & & $2,47 \pm 0,29$ \\
\hline
\end{tabular}


Hasil analisa statistik terhadap data ini menunjukkan probabilitas kecil dari 0,05. Artinya pemberian ekstrak etanol bunga kecombrang dapat menurunkan kadar MDA secara signifikan. Dari ke 3 dosis yang diberikan terlihat pada dosis $400 \mathrm{mg} / \mathrm{kgBB}$ memberikan efek yang paling bagus dimana kadar MDA nya menurun mendekati MDA kontrol negatif.

Hasil perhitungan statistik analisa varian (ANOVA) satu arah terhadap kadar MDA serum mencit terlihat signifikan yang dinyatakan dengan $\mathrm{P}<0,05$ antara kelompok yang diberikan sediaan uji terhadap kelompok kontrol positif dan negatif.

Uji lanjut Duncan memperlhatkan bahwa kadar MDA rata-rata pada seluruh kelompok dengan variasi dosis ekstrak etanol bunga kecombrang, kontrol negatif berbeda nyata dengan kontrol positif. Kelompok dosis 100 $\mathrm{mg} / \mathrm{kgBB}$ juga berbeda nyata dengan kelompok dosis $200 \mathrm{mg} / \mathrm{kgBB}$ dan dosis $400 \mathrm{mg} / \mathrm{kgBB}$. Namun kadar MDA kelompok dosis 200 $\mathrm{mg} / \mathrm{kgBB}$ dan kelompok dosis $400 \mathrm{mg} / \mathrm{kgBB}$ mendekati kadar MDA kontrol negatif.

Dari hasil penelitian yang dilakukan dapat terlihat bahwa ektrak etanol bunga kecombrang mampu menurunkan kadar MDA mencit dan itu berarti ektrak etanol bunga kecombrang pada dosis $200 \mathrm{mg} / \mathrm{kgBB}$ dan $400 \mathrm{mg} / \mathrm{kgBB}$ dapat digunakan sebagai antioksidan.

\section{KESIMPULAN}

Dari hasil penelitian yang telah dilakukan dapat diambil kesimpulan bahwa pemberian ekstrak etanol bunga kecombrang selama 14 hari dapat menurunkan kadar MDA serum mencit diikuti dengan penurunan kadar kolesterol mencit, dimana pada uji duncan efek paling efektif terdapat pada dosis $200 \mathrm{mg} / \mathrm{kgBB}$ dan dosis $400 \mathrm{mg} / \mathrm{kgBB}$ yang kadar MDA nya hampir mendekati kontrol negatif.

\section{SARAN}

Diharapkan untuk peneliti selanjutnya dapat meneliti aktivitas lainnya dari bunga kecombrang.

\section{DAFTAR PUSTAKA}

Manimaran \& Rajneesh C.P. (2009). Activities of Antioxidant Enzyme and Lipid Peroxidation in Ovarian Cancer Patients. Biomedical Research, 2, 68-72.

Helmizar, Jalal, F., \& Liputo, I. (2010). Hubungan Tingkat
Konsumsi Antioksidan dengan Profil Lipid Darah Orang Dewasa Etnis Minangkabau di Kota Padang. Majalah Kedokteran Indonesia, 60(8), 356-363.

Heryani, R. (2016). Pengaruh Ekstrak Buah Naga Merah Terhadap Profil Lipid Darah, 1, 8-17.

Jaffar S. Fruton \& S. Simmonds. (1963). Biochemistry. New York: John Wiley \& Sons Inc.

Harborne. (1987). Metoda Fisikokimia Penuntun Cara Modern Menganalisis Tumbuhan (Terbitan K). Bandung: ITB.

Kusumawati, E., Supriningrum, R., \& Rozadi, R. (2015). Uji Aktifitas Antibakteri Ekstrak Etanol Daun Kecombrang (Etlingera elatior ( Jack ) R . M . Sm.) Terhadap Salmonella typhi, 1(1), 1-7.

Latifa, K. E. N. I. (2015). Profil kadar mda (malondialdehide) pada tikus yang diberikan ekstrak herba thymi. Naskah Publikasi, Farmasi, Fakultas Surakarta, Universitas Muhammadiyah, 1-10.

Marsk, Dawn B., Allan D. Marsk., C. M. S. (2000). Biokimia Kedokteran Dasar. Jakarta: EGC Kedokteran.

Naufalin, R., \& Rukmini, H. S. (2016). Antioxidant Activity and Physicochemical Properties of Nicolaia speciosa Flower Extract. Italian Oral Surgery, 9(1995), 297303. https://doi.org/10.1016/j.aaspro.2016.02.132

Rahayu, T. (2005). Kolesterol, Kadar Tikus, Darah Pemberian, Setelah Kombucha, Cairan Cholesterol, Per-oral Blood Of, Degree Rat, White Getting, After Fluid, Kombucha Pendidikan, Jurusan Fkip, Biologi Muhammadiyah, Universitas Abstrak, Surakarta, 85100.

Ganiswara G. (1995). Farmakologi dan Terapi (IV). Jakarta: Gaya Baru.

Saludung, J. (2015). Sirup kecombrang josani aneka rasa.

Soobrattee, M. . (2005). Phenolic as potential antioxidant therapeutic agents: mechanism and actions. Mutation Research, 579, 200-213.

Thompson EB. (1990). Drug Bioscreening Fundamental Of Drug Evaluation Techniques In Pharmacology. (Publishing Company, Ed.). New York: Inc.

Valco, M., C.J. Rhodes., J. Mocol., M. Izakovic., and M. M. (2006). Free radical, Metal and Antioxidant in Oxidative Stress Inducced Cancer. ChemicoBiological Interaction, 160(1), 1-40.

Winarsi, H. (2007). Antioksidan Alami dan Radikal bebas Potensi dan Aplikasinya dalam Kesehatan (2nd ed.). Yogyakarta: Kanisius. 